1 This article was written by the author based on her master research project, the results of which are recorded in the dissertation entitled "Sob a 'Lente do espaço vivido': a apropriação da rua pelos blocos de carnaval na Belo Horizonte contemporânea". The research was finalized in March 2015 on the Post-Graduate Programme in Architecture and Urbanism at the Universidade Federal de Minas Gerais, under the supervision of Dr. Ana Paula Baltazar dos Santos.

\section{THE APPROPRIATION \\ OF STREETS IN BELO HORIZONTE BY CONTEMPORARY CARNIVAL BLOCKS ${ }^{1}$ CARNIVAL BLOCKS'}

\section{A APROPRIAÇÃO DAS RUAS DE BELO HORIZONTE PELOS BLOCOS DE CARNAVAL CONTEMPORÂNEOS}

\author{
Paola lisboa Codo Dias \\ Prefeitura Municipal de Belo Horizonte, \\ Secretaria Municipal Adjunta de Planejamento Urbano, Belo Horizonte, MG, Brasil
}

A B S T R A C T : Carnival blocks (roving carnival street parties) in Belo Horizonte have emerged ever since the city was first founded in the late nineteenth century. However, during the 1930s, this kind of carnival manifestation went into decline and lost its importance. During the 1990s, Belo Horizonte became known for its quiet, peaceful streets during the carnival holiday period. However, the first decade of the twenty-first century marked a change in this process during the pre-carnival period, and 2009 marked the beginnings of a movement to re-establish street carnival blocks during the official carnival holiday period. Over the years, carnival in Belo Horizonte has undergone a complete transformation, moving from a decadent festival, marginalized and almost forgotten by most of the population to a very successful effervescent, exuberant celebration. Hence, this article aims to introduce discussions and some unusual perspectives regarding space in the contemporary metropolis with a reflective viewpoint regarding appropriation of the city by carnival celebrations.

K E Y W O R D S : socio-spatial appropriation; street carnival; contemporary carnival street blocks; festive, political manifestations; socio-spatial conflicts in the metropolis.

Contemporary street carnival blocks (roving carnival street parties) are a manifestation resulting from a long historical process, the origins of which are linked to the Portuguese colonization process and the socioeconomic and political relations that transpired between Brazil and other European countries. With such close links between the former Portuguese colony and the old continent it was inevitable that there would also be a number of cultural exchanges, of which carnival is one example, whereby an originally European festival has been incorporated into the Brazilian calendar of popular celebrations, ever since the first decades of the sixteenth century.

However, the popular carnival activity known as carnival blocks only really surfaced in the early twentieth century, concurrently with other popular (often working class) manifestations known as ranchos and cordöes. Compared to other successful manifestations of that time, these carnival blocks represented a more 
unpretentious, free, good-humoured form of celebrating carnival in the streets of Brazilian cities. Throughout the twentieth century, this model was subdivided into a number of subtypes, such as the African blocks in Salvador, the caricato (as in caricature) blocks in Belo Horizonte, the embalo and enredo blocks in Rio de Janeiro, the lyrical, frevo and maracatu blocks in Recife and Olinda, and the blocos dos sujos in various other cities across Brazil.

With the exception of specific contexts, such as Salvador, Recife and Olinda, throughout several decades the street carnival blocks gradually lost their importance and dimension in relation to other forms of carnival celebrations. However, there has been a recent transformation, and since the late 1980s the street blocks have been revived, and have been attracting an ever-increasing number of revellers, not only in the pioneering city of Rio de Janeiro (PIMENTEL, 2002), but also in several other major Brazilian cities from the 2000s, such as the metropolis of São Paulo (AGENDA, 2015; ROLNIK, 2015), Brasília (ATTEND, 2015; ACOMPANHE, 2015; GUIA DOS BLOCOS TRADICIONAIS DE BRASÍLIA, [201?]) and Belo Horizonte. Within this contemporary transformation of Brazilian carnival, the newest form that carnival revellers have most adopted is the so-called street carnival blocks.

For the purposes of this article, contemporary street carnival blocks are defined as self-organized groups of people whose main aim is to celebrate carnival in the city, through the playful, spontaneous, free and non-institutionalized appropriation of the city streets, avenues, squares and other public spaces. However, this festive appropriation has consequently highlighted ideological and practical conflicts regarding the most desirable uses for Brazilian cities and metropolises within a contemporary socioeconomic and political context.

Therefore, cities and metropolises with more consolidated carnival traditions deal with the conflicts of appropriating public spaces, emphasised by this major popular Brazilian festival, in a less complicated and more negotiable manner than those with less carnival tradition. Thus, while for example, the local governments of São Paulo and Belo Horizonte have regarded certain issues in relation to street carnival as a hindrance, such as dealing with the large numbers of people on the streets, closing streets, clearing garbage and the need for security, these same problems are treated as commonplace in cities like Rio de Janeiro, Salvador, Recife and Olinda, where carnival celebrations are greater in size, scope, and fame, and where the importance of social, cultural, economic aspects and tourism are more consolidated.

The architect Raquel Rolnik analysed the case of São Paulo (2015) and concluded that "The notable growth of street carnival is part of a much broader ongoing movement within the city, which is claiming public spaces and appropriating places for meetings, culture, sports and festivities". Besides carnival, many other festive and sporting events have increasingly made use of avenues, tunnels, parks and squares in the city of São Paulo, marking a cultural change in the "way to see and live the city" as well as "the inhabitants themselves" (ROLNIK, 2015, author's translation).

Rolnik (2015) argues that the current appropriation of public spaces challenges the city council to recognize and deal with recent changes in the relationship between big cities and their inhabitants. In the context of street carnival in São Paulo, it was no longer fitting for the Government to disregard it or repress it through the use of police action, and, "in recent years, finally, the city has endeavoured to plan and organize the festivities." (ROLNIK, 2015, author's translation). The issues 
raised by this researcher in the case of São Paulo are similar to what has occurred in Belo Horizonte since 2009. However, within this scenario there are specific issues, especially with regard to a certain group of street carnival blocks that have proposed a carnival, which is more political and demanding in nature.

Indicated by several sources as being mainly responsible for the return of carnival revellers to the streets of Belo Horizonte, the historian and musician Guto Borges (2013) confirms that there has been a proposal to confound carnivals and revolutions. In February 2013, Borges argued that, in Belo Horizonte, contemporary street carnival blocks proposed a new manner with which to view the city, which went beyond the merely functional, and negotiated the use of streets by extending it past many other private worlds represented by cars, seeking to relate to other people through contact and joy, becoming united in the streets by affection and love, creating politics out of everyday life and putting it into practice, challenging the sometimes violent measures of the Government that aim to restore the order of silence and the anti-city. Finally, for this activist and self-declared carnival reveller the aim of the blocks was to unite carnival festivities with a radically democratic and libertarian spirit.

The aim of this study is to examine the movement that brought street carnival back to Belo Horizonte (the state capital of Minas Gerais) at the beginning of the twenty-first century, considering the stated purpose of the first contemporary street blocks to mix festivities with politics, carnival with revolution, city with mobilization, streets with struggles, freedom with negotiation and democracy with love.

\section{THE EMERGENCE OF STREET CARNIVAL BLOCKS IN BELO HORIZONTE DURING THE TWENTY-FIRST CENTURY}

Street carnival blocks first started to emerge in Belo Horizonte at the time of its founding in the late nineteenth century, and although they never actually totally disappeared, this kind of carnival manifestation began to diminish in size and importance as from the 1930s. This same process was also occurring with other types of carnival events within the state capital, such as the old carnival clubs, the cordóes and corso parades. On the other hand, the samba schools and caricato blocks, carnival types which appeared between 1930 and 1940, were responsible for keeping carnival revelry alive for a few more decades. However, by the 1990s, Belo Horizonte had become known for the peace and quiet that reigned over its streets during the carnival holiday, especially since a large number of people left the city, either searching for livelier carnival destinations or simply fleeing the urban environment in search of refuge closer to nature.

However, from the first decade of the current century, the emergence of new carnival associations created by groups of friends living in Belo Horizonte marked a turning point in this process. From the early 2000s to the present day, the city of Belo Horizonte has undergone a historic transformation regarding its carnival. The year 2004 was highlighted by the formation of a pre-carnival group called Santo Bando, which was the first of a new crop of carnival blocks that drew thousands of revellers to the streets of Belo Horizonte (BRANT, 2012), raising, unintentionally, 
controversies and conflicts concerning the appropriation of public places by a festive multitude.

In the biennium 2009-2010, the first major expansion of street carnival occurred when several other blocks were established, and which have already come to be considered traditional in the Belo Horizonte street carnival, both during the pre-carnival period as well as during the official carnival holiday. In 2009, three blocks were created, and in 2010, seven new blocks appeared (PODIA SER PIOR et al., 2012), many of them influenced by a movement that claimed the right to use a square called Rui Barbosa ${ }^{2}$, and known as Praia da Estação (Station Beach). This movement emerged in January 2010 as a reaction to a local government decree that legally imposed restrictions on holding events of any kind in the square (BELO HORIZONTE, 2009). Organised through the Internet, Praia da Estaçâo offered a new form of civil political expression, by proposing an urban intervention with performances and festivities metaphorically transforming the square (Praça da Estação) into a kind of beach (IMAGINA NA COPA, 2013).

Figure 1: Festive appropriation and contestation of Praça da Estação in Belo Horizonte, during the first occupational movement Praia da Estação, on January $7^{\text {th }} 2010$

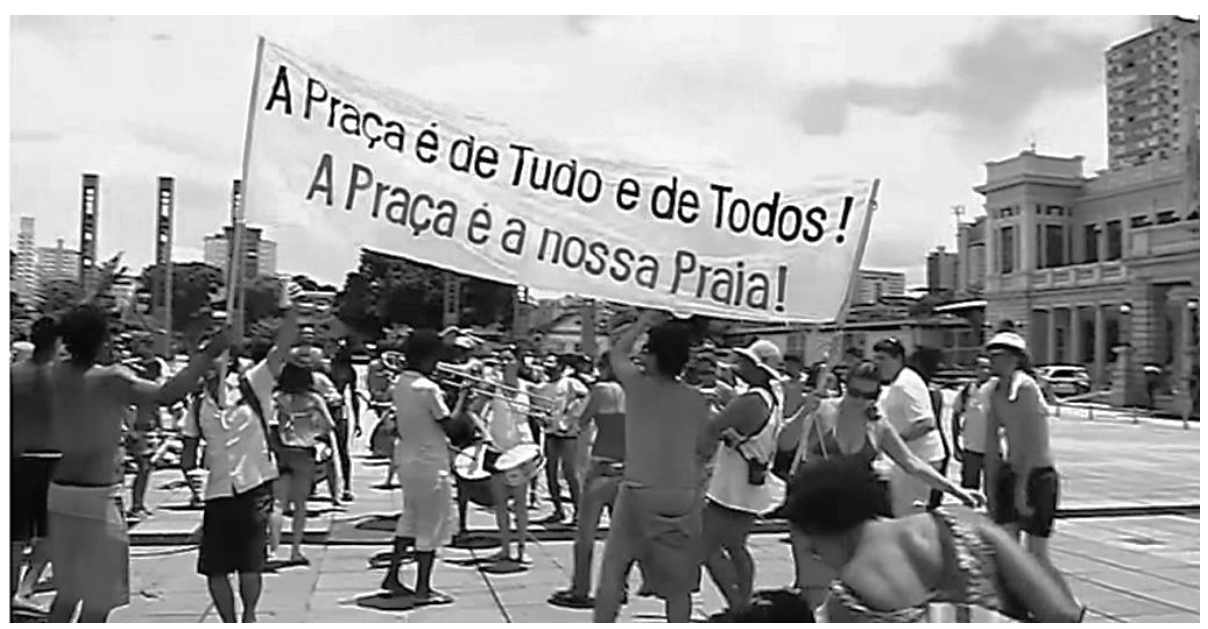

Source: Praça Livre BH (2010).

After much controversy, this legal determination was eventually repealed five months later (BELO HORIZONTE, 2010). However, this prohibitive act, although temporary, had helped to create a movement that claimed the right to use and appropriate the city's public spaces, and which has grown and consolidated over the past six years. Furthermore, the following year, the Praia da Estação created its own street carnival block.

Hence, it may be observed that carnival blocks in Belo Horizonte have originated from the same non-institutionalized, non-partisan civil movement, mostly made up of well-educated, intellectual young people from the middle-class, who have benefited greatly from internet resources and social networks in order to organise themselves. The movement has sought not only to bring back street carnival, but mainly to claim the right to use and appropriate public spaces within the state capital. These actions have arisen in response to a number of management and cut back measures adopted
2 This space is popularly known as Praça da Estação (Station Square), since this is where both the protected buildings of the old Brazil Central Railway Station, and the current Museum of Arts and Crafts (MAO) stand. The square still contains one of the entrances to the Belo Horizonte Subway (Estação Central), which not only leads to the subway but also to the passenger railway services which operate daily between Vitória and Belo Horizonte (EFVM). 
by the mayor of Belo Horizonte, Marcio Lacerda, who took over as Mayor in January 2009, and who is currently in his second term of office.

During the period between 2011 and 2013, thousands of revellers were attracted to street carnival blocks, which was not well-received by the state capital authorities, such as the Fire Department, the State Prosecutor, the Military Police, the City Council and a number of management institutions from within the municipal public services, such as BHTrans (the transport and traffic company) and Belotur (the tourism company). Instead of interpreting the carnival block parades as a cultural event, these departments viewed them as an event which, according to local legislation within the city's Codes of Practice (BELO HORIZONTE, 2003), needed prior authorization in order to go ahead. Thus, the authorities began to require certain measures regarding the carnival blocks, such as fencing off specific areas, limiting the number of participants and a project for accident prevention (DESFILE, 2012; TRADICIONAL, 2012).

Even with all these official measures and legal impediments, it was insufficient to dampen the spirits of the people in Belo Horizonte, who yet again appropriated the city's streets and squares in order to enjoy the carnival festivities. Hence, with each carnival, new groups are being created, inspired and encouraged by the success of the previous years. Over the past six years, street carnival blocks have been increasing, consolidating and attracting an ever-growing number of revellers. The phenomenon culminated in 2015 with a procession of around 180 carnival blocks throughout the city's streets, several of which attracted many thousands of revellers, others united tens of thousands and the very biggest conducted 100,000 people towards the area surrounding Praça da Liberdade, and the very centre of Belo Horizonte on carnival Monday (ALMEIDA, 2015).

This significant increase in the number of carnival blocks and their revellers has caused the City Council to rethink its attitude not only towards them but also towards carnival as a whole. Consequently, in 2014, the municipal government announced, through its tourism agency Belotur, a huge infrastructure and schedule that featured 14 stages mounted across the various neighbourhoods of the capital presenting many different shows, in addition to a return of the official parades by the samba schools and caricato groups along the most prominent avenue in the city: Ave. Afonso Pena (BELO HORIZONTE, 2014). In 2015, this same structure was maintained and expanded to include two special stages for children, one located in the city centre and another in the region of Pampulha (BELO HORIZONTE, 2015). That same year, even the private tourism sector became involved, by launching holiday packages for those interested in enjoying the carnival festivities in Belo Horizonte, as well as offering options to visit the natural attractions in and around the central region of the state of Minas Gerais (MIRANDA, 2015; ALVARENGA , 2015).

Thus, the context of the last two years has represented a conflicting, although very successful, mixture for the carnival festivities, so much so that with each coming year, the largest carnival in the history of Belo Horizonte is announced. In the year 2014, one million revellers (MUZZI, 2014) took to the streets and in 2015, 1.5 million people (ALMEIDA, 2015) appropriated not only the streets, squares, alleyways, lanes, walkways, overpasses, buses, subway but also the virtual spaces social networks, blogs, web sites and applications - in a manner which in most cases, was festive, happy, political, engaged, democratic and peaceful. 
On one hand, while this mixture has presented a movement through which appropriation of the city has been restored through the street carnival blocks, which were originally created through the initiatives of residents during the first decade of this century, on the other hand, in direct response to the increasing number of street blocks, we may also observe a growth and strengthening of the official carnival organized by the City Council, together with an emerging interest within the private sector, seeking profits from investing in the Belo Horizonte carnival.

\section{"CARNIVAL OF THE STREETS AND STRUGGLES"3}

On February $2^{\text {nd }} 2015$, prior to the carnival celebrations of that same year, a video entitled Sobre carnavais e revoluçôes (About carnivals and revolutions) was released on YouTube ${ }^{4}$, and spread quickly through Facebook ${ }^{5}$. According to its creator and director, Fred França (2015), the aim of this video was to examine the Belo Horizonte street carnival, especially that of 2014, from the perspective of the historian, musician and reveller Guto Borges - one of those chiefly responsible for restoring street blocks to Belo Horizonte.

On February $25^{\text {th }}$, 2015, during the post-carnival period, the carnival revellers Guto Borges, Roberto Andrés Gustavo Caetano and Rafael Barros were interviewed by the radio host Eduardo Costa on the programme Chamada Geral on Radio Itatiaia. The four of them, respectively, were representing the groups they had founded, the forerunner blocks Mama na Vaca, Unidos do Samba Queixinho Underground Baticum, Tico Tico Serra Copo and Filhos de Tcha Tcha. During the interview, which lasted around thirty minutes, various contemporary issues on the Belo Horizonte carnival came under discussion, such as the democratic occupation of the streets, squares and other public spaces, interpreting the blocks as a cultural manifestation, conflicts with the City Council and the Military Police, as well as the change in attitude adopted by local government over the last two years regarding carnival (COSTA, 2015).

On the very same day (25th February), the first part of the mini-documentary Samba e Suor (Samba and Sweat) produced by photojournalist Leo Fontes was posted on YouTube and the online page of the newspaper $O$ Tempo. The second part of the mini-documentary was released on March 5 $5^{\text {th }}, 2015$, also online. The aim of the videos, according to its makers, was to portray the transformation that has taken place in the Belo Horizonte carnival, with emphasis on its strongly political, demanding, revolutionary appeal (FONTES, 2015a; 2015b).

On March 14 $4^{\text {th }}, 2015$, the first screening of the film ISIDORA: Carnaval e luta (ISIDORA: Carnival and struggle)" took place at the Ocupação Vitória (the Victoria Squat). According to the disclosure published on Facebook, this short film records the meeting of the abovementioned block, Filhos de Tcha Tcha with the homeless and landless squats located in the region of Isidoro (NAESSA, 2015). During 2014 and 2015, the Filhos de Tcha Tcha made its carnival procession along the dirt roads of the squats, with no urban infrastructure, known as Rosa Leão, Esperança and Vitória, as a way of giving symbolic support to the struggle for decent housing in big cities.

The Rosa Leão squat appeared in May 2013, and the others, Esperança and Vitória, were created in July of that same year, very much encouraged by the context
3 "Carnival of the streets and struggles": an expression used by many street carnival blocks in Belo Horizonte to register the spirit of the festive, political, demanding struggle of/in the city.

4 YouTube is a major site for sharing videos on the internet (DICKEY, 2013).

5 Facebook is the largest worldwide social network on the internet, created in 2004 (FACEBOOK, 2015). 
of the Jornadas de Junho - referring to a series of political demonstrations throughout many different cities across the whole of Brazil in June 2013, which brought millions of people onto the streets. Currently, according to data from the movement itself, the Rosa Leão, Esperança and Vitória squats are home to around 1,500, 2,500 and 4,500 families, respectively (OCUPAÇÃO ROSA LEÃO, [201-?]; OCUPAÇÃO ESPERANÇA, [201-?]; OCUPAÇÃO VITÓRIA, [201-?]. All are located in the region known officially as Isidoro (terminating in "O") or, according to militants within the movement, Isidora (terminating in "A"). The region, located in the far north of Belo Horizonte, is the very last large vacant plot of land owned by the municipality, and is also of great environmental relevance. According to official data, this region is larger than the area originally planned and implemented at the end of the nineteenth century to accommodate the entire urban area of the new capital of the state of Minas Gerais (BELO HORIZONTE, [201-?]).

Figure 2: Appropriation of the dirt roads in the Rosa Leão squat, on the borders of the municipalities of Belo Horizonte and Santa Luzia, by the carnival block Filhos de Tcha Tcha, in 2014

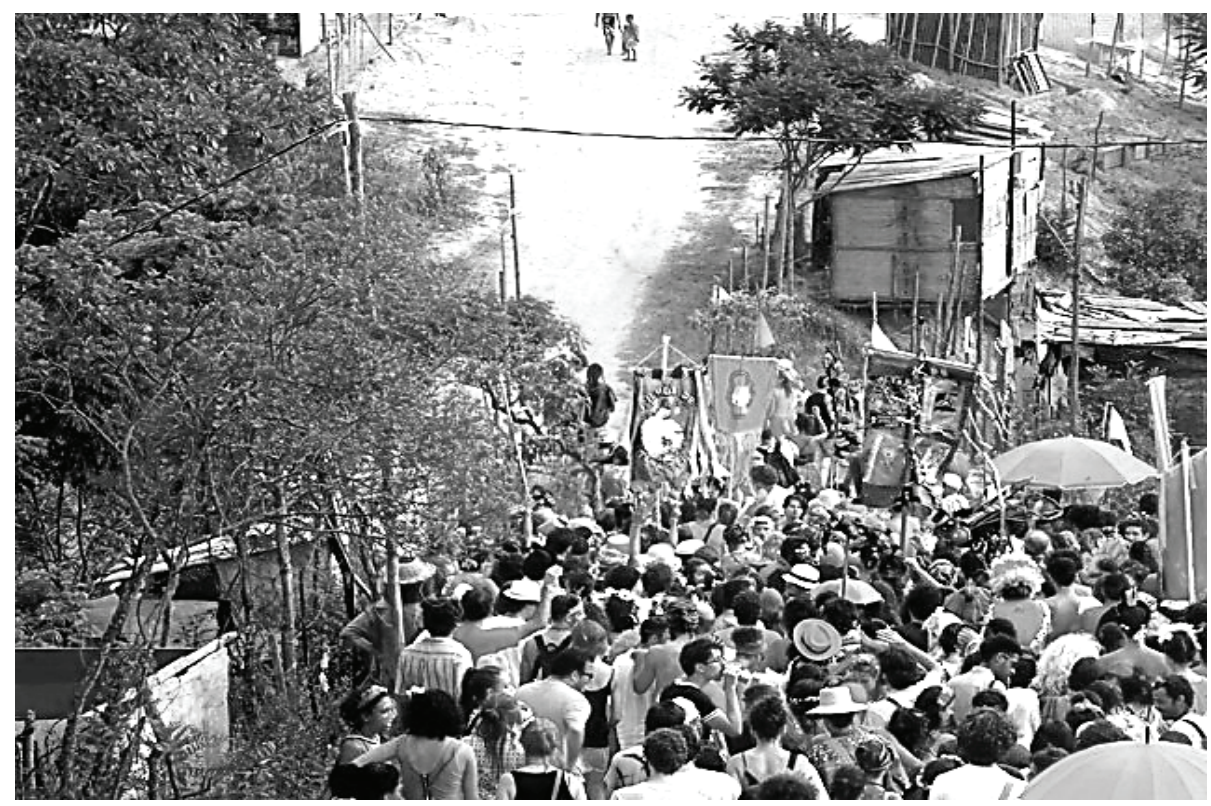

Source: Jorge (2014).

6 Through the publication of the Manifesto de docentes em solidariedade às Ocupações do Isidoro.

7 The Observatório das Metrópoles is a research institute that unites researchers, university institutions, government departments and non-governmental organizations, under the coordination of IPPUR - The Research and Urban and Regional Planning Institute at the Universidade Federal do Rio de Janeiro.
In July 2013, a court order determined the repossession of occupied land in the Isidoro region by the city council of Belo Horizonte and other private owners (JUSTIÇA, 2014). Under threat of repossession in August 2014, the Brazilian Order of Lawyers in Minas Gerais (OAB-MG), the State Prosecutor (MPMG) and the State Public Defender filed lawsuits to suspend the eviction orders (DINIZ; SANTOS, 2014). At the same time, there was considerable public pressure for the homeless families to remain on the site, and the movement Resiste, Isidoro was created, with the support of over five hundred academics from all over the country (OBSERVATÓRIO DAS METRÓPOLES, 2014) ${ }^{6}$, with the solidarity of the Observatório das Metrópoles ${ }^{7}$. Until completion day of this article, in September 2015, the removal process of these families was still pending. 
The above examples demonstrate that in the case of Belo Horizonte, several street carnival blocks, through their diversity of flags, costumes and games, upheld a variety of political, social and spatial banners, and caused an impact far beyond the traditional period of carnival revelry and themes. In this respect, many blocks in Belo Horizonte, due to the tone of their demands and claims, are easily recognised by other revellers as being those who either defend the appropriation of various types of public spaces, marginalized areas, neighbourhoods, suburbs, villas and favelas (the Praia da Estação, Tico Tico Serra Copo, Pena de Pavão de Krishna and Então, Brilha blocks), or who support popular housing movements (the Filhos de Tcha Tcha and Tico Tico Serra Copo blocks), or who wave the banner for creating free spaces for cultural production (the Blocomum block) and those related to the causes of public transport and urban mobility (Bloco Pula Catraca! - Associação Carnavalesca Antitarifária and Bloco da Bicicletinha).

Figure 3: The pedestrian walkway that crosses the railway lines in Belo Horizonte, appropriated by the carnival block Tico Tico Serra Copo, in 2013

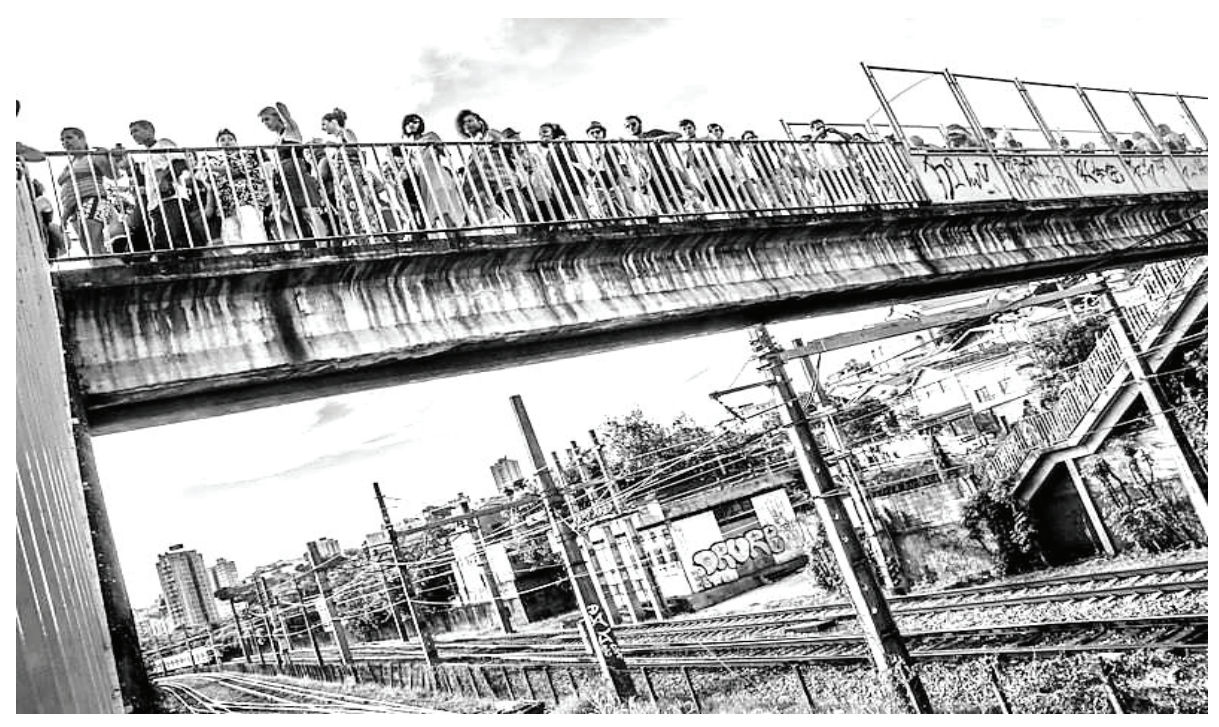

Source: Leite (2013).

\section{JORNADAS DE JUNHO, URBAN ACTIVISM AND CARNIVAL BLOCKS}

In the politically effervescent context following the abovementioned Jornadas in June 2013, two other important movements emerged in Belo Horizonte: Tarifa Zero BH (Zero Fare BH) and the Espaço Comum Luiz Estrela (Luiz Estrela Common Space). By carnival of the following year, these two movements had already founded their own carnival blocks.

The Tarifa Zero BH movement appeared as a direct result of the demonstrations that took place in Belo Horizonte in 2013. The history of the movement started with the $2^{\text {nd }}$ Assembleia Popular Horizontal, according to a report by one of its representatives, André Veloso (2014), published on the website of the movement in 
8 ComUrb was created on $2^{\text {nd }}$ September 2013, by Decree no 15.318 (BELO HORIZONTE, 2013).
June 2014. This meeting took place on June $23^{\text {rd }}, 2013$ and included the participation of more than 2,000 people. The next day, the largest protest to be seen in the state capital until that moment took place: 60,000 people marched approximately $7 \mathrm{~km}$ from Praça Sete to the City Centre, towards the Mineirão stadium, in the Pampulha region, during one of the matches of the Confederations Cup that was being held in Belo Horizonte. In the $2^{\text {nd }}$ Assembleia Popular Horizontal, the Working Groups Organization (known as GTs) decided on themes that would address different issues of interest to the participants: from police repression to political reform.

Amongst the groups formed on that occasion, was the Urban Mobility GT which, thereafter, began to hold weekly discussions, thus gaining autonomy from Assembleia Popular Horizontal meetings. During the discussion process, the group concluded that "the crux of the matter" regarding urban mobility in the city was the abolition of public transportation fares and accordingly, drew up the proposal for a popular initiative bill. Until completion day of this article, in September 2015, the bill had not yet been sent to the City Council.

However, it was from this proposal that the Urban Mobility GT came to be known as Tarifa Zero BH, which until today is used by several actions of popular participation. According to one of its representatives (VELOSO, 2014), members of the movement participated in public debates, actions in schools, guided reports and condemned favouritism. In addition, they participated in institutional proceedings, such as the various activities of the Municipal Urban Policy Conference, which took place between the $2^{\text {nd }}$ half of 2013 and the $1^{\text {st }}$ half of 2014, elected members to the Regional Committee of Transport and Traffic and to the then newly-created Municipal Council for Urban Mobility - ComUrb ${ }^{8}$.

In addition to the aforementioned actions, the Tarifa Zero movement also created the block named Pula Catraca - Associação Carnavalesca Antitarifária ("Jump the Turnstile - The Anti-fare Carnival Association", since buses in Brazil have turnstiles), "which made its debut parade on pre-carnival Sunday in the year 2014. That same year, the Pula Catraca carnival music was also released, which eventually won $2^{\text {nd }}$ place in the $3^{\text {rd }}$ Mestre Jonas Carnival Music Contest, promoted through a partnership between local radio and an events promoter in Belo Horizonte, with support from the municipal and state governments (BLOCO PULA CATRACA!, 2014; BAETA, 2014).

Still during Carnival 2014, the movement provided free transportation for the revellers as a creative and proactive manner of protest, the so-called Carnival with no turnstiles. Accordingly, the Tarifa Zero movement, using its own resources, provided two buses that circulated free of charge along three different routes during the four days of Carnival - Saturday to Tuesday (CAMILO, 2014; TARIFA ZERO BH, 2014a). In 2015, the free bus, entitled Busona Tarifa Zero, ran three different routes between Saturday and Monday of Carnival. In 2015, according to its organizers, the success of the proposal was so great that it was necessary to bring in additional buses to meet the demand, both on Sunday and Monday of Carnival (TARIFA ZERO BH, 2014a; 2015a). 
Figure 4: Free bus timetable and routes organized by Tarifa Zero BH during the 2014 carnival in Belo Horizonte

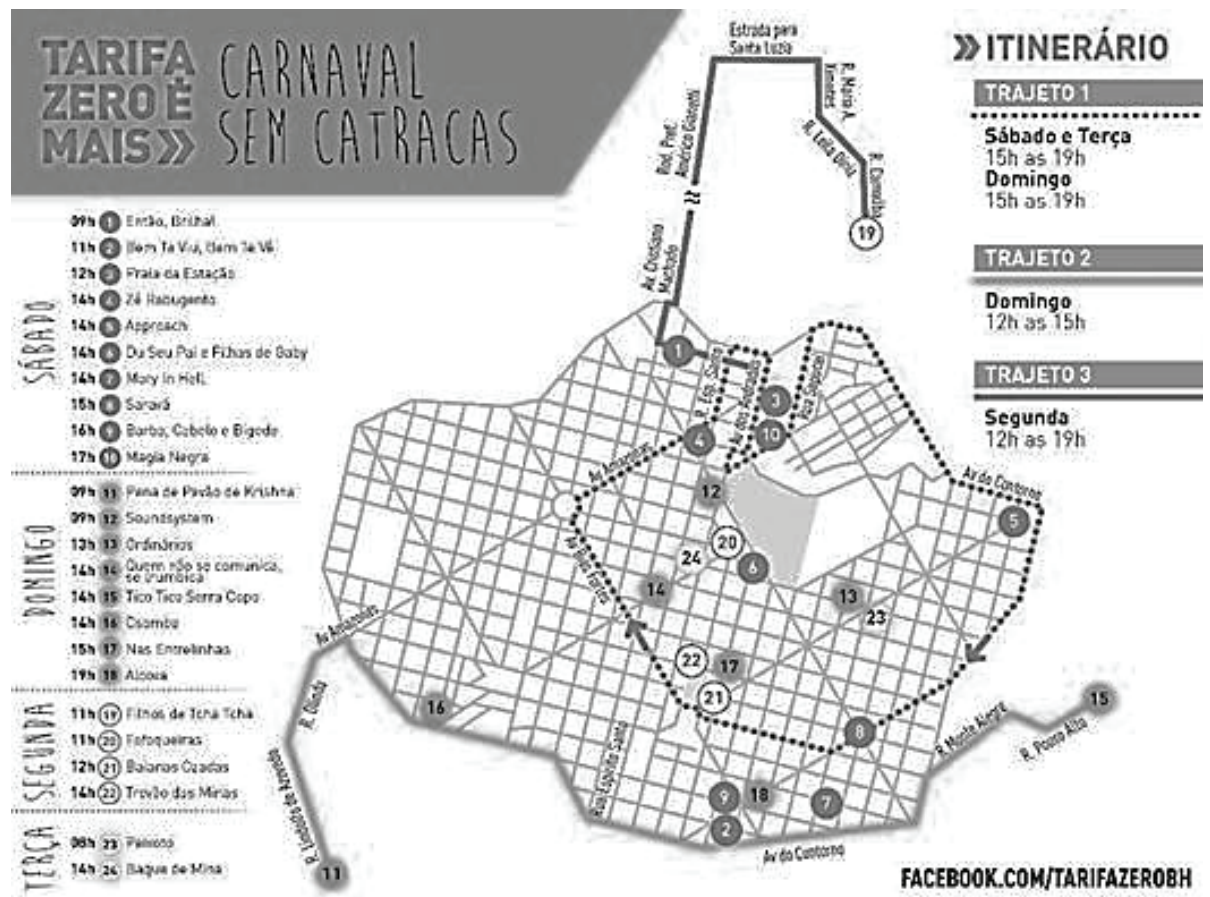

Source: Tarifa Zero BH (2014b).

During these two years of mobilization, the Busona Tarifa Zero ran a timetable along routes that not only served areas with the highest concentrations of revellers during the Belo Horizonte carnival, but also included areas that were further away and more difficult to get to, and which had been chosen to receive the processions of the carnival blocks Tico Tico Serra Copo, Filhos de Tcha Tcha and Pena de Pavão de Krishna. Thus, the Busona transported revellers to districts in the South-Central region, such as Centro, Savassi, Funcionários, Santa Efigênia and Serra; districts in the East, such as São Geraldo and Esplanada; and districts in the Northwest and West, such as Lagoinha and Jardim América. Furthermore, bus routes also included some of the main roads of Belo Horizonte, such as the Contorno, Cristiano Machado, Amazonas, Andradas Avenues and the MG-010 highway. The routes also transported revellers to the villages and favelas that make up the Aglomerado da Serra as well as the homeless squats in the region of Isidoro, access to which is through the neighbouring municipality of Santa Luzia (TARIFA ZERO BH, 2014a; 2015b).

Another block strongly associated with Bloco Pula Catraca! - Associação Carnavalesca Antitarifária is the Blocomum, which was also created in 2014 by the Espaço Comum Luiz Estrela. In 2015, the meeting point for the Pula Ratchet block was right outside the City Hall, before heading towards the Subway Station Santa Tereza, where an act of protest was held against the prices of public transport, after which they joined their comrades from Blocomum on the streets of the Santa Efigênia. Thus, over the last two years, these two blocks have paraded together on pre-carnival Sunday on the streets of Belo Horizonte (TARIFA ZERO BH, 2014a; 2015a).

The Espaço Comum Luiz Estrela is an open, self-managed cultural centre created for the development of free artistic training. According to information released by the 
centre, it aims to enable the existence of cultural production free from the market and institutional mechanisms of cultural incentives (ESPAÇO COMUM LUIZ ESTRELA, 2013). The site on which the cultural centre stands is owned by the Foundation Hospital of Minas Gerais (known as Fhemig), and since 2012, has been conceded to the Lucas Machado Educational Foundation (Feluma), an institution maintained by the Faculty of Medical Sciences of Minas Gerais (ROCHA; MARTINS, 2013). The property is an old mansion protected by the city's Cultural Heritage Foundation, and is situated in a highly sought after, central district of Santa Efigênia. However, for almost 20 years it had been left empty and in a state of abandonment. Therefore, there was a mobilization, formed by a group of activists and artists and organised through the internet, to occupy the house on $26^{\text {th }}$ October 2013. After two months of resistance and negotiation with local government, on December $16^{\text {th }}$, 2013, the State Government of Minas Gerais conceded the right to use the property for the artistic-cultural project Espaço Comum Luiz Estrela (CRUZ, 2014).

At the time of its occupation, at the end of 2013, the mansion was in danger of imminent collapse. Thus, the group that currently manages the Espaço Comum Luiz Estrela undertook emergency works in order to shore up the property. Part of the funding for this work was acquired through the Programa Adote um Bem (Adopt an Asset), from the City of Belo Horizonte's Heritage Executive ( $\mathrm{R} \$ 40,000)$, and another part was obtained through public funding via a virtual page ( $\$$ \$2,000). Later, at a public hearing held at the Legislative Assembly, they requested a budget of $\mathrm{R} \$ 2$ million for "the second stage of the rebuilding programme to undergo improvements to the roof and the facade, and the removal of a screening slab that poses a risk to the structure." (CRUZ, 2014, author's translation). However, they were unsuccessful in receiving the amount requested, and the parliamentary amendments obtained only $\mathrm{R} \$ 100,000$ from the 2014 municipal budget for this purpose.

Therefore, the managers of the Espaço Comum Luiz Estrela announced that cultural activities would continue alongside the works and the struggle to raise the financial resources necessary in order to complete the restoration works. In this aspect, one of the movement's activists, the architect Priscilla Musa from the nucleus of memory and restoration of the space, stated that "We want this mansion to wear the face of denunciation" (MUSA apud CRUZ, 2014, author's translation). Therefore, the restoration project intends to maintain the layers of peeling masonry, and the cracks and traces through which we are able to recognise the property's history.

Hence, behind the apparent lack of commitment, suggested by the joy, jokes and revelry of carnival, traditional expressions of the willingness to surrender to the desires of the body and the flesh before the sacrifices of lent, there exists a broad agenda of claims and demands that have repercussions in other spheres of the everyday urban life of the state capital of Minas Gerais. Thus, the blocks in Belo Horizonte, pioneers in the movement to restore street carnival have structured themselves not only to organise the festive processions during the carnival holiday period, but also to become mobilized throughout other periods of the year in support of political banners related to important issues regarding the contemporary city: public spaces, housing, urban mobility, culture, heritage, public policy and management. 


\section{FINAL CONSIDERATIONS}

The return of street carnival blocks to Belo Horizonte has a common origin, engendered by a non-institutionalized, self-managed movement to occupy various public spaces of the city, mixing political demands with festive demonstrations. These pioneering blocks have organized themselves through self-management and self-financing, have refused public and private sponsorship, and are not profitoriented. Their proposal is to occupy the city, reinvent spaces, connecting people and bringing poetry and joy to everyday life, but by also raising questions on the urban environment, including those who are excluded and marginalized, and reproving the questionable actions of political and economic power.

Within this context, the hegemonic powers have not yet discovered how best to deal with this kind of movement, which is organised within the scale of living space, that of everyday life, and which is not captured by institutional actions. This is a movement that mixes people who do not know one another, but who have common interests and ideas, who propose new discussion spaces both virtual and real time, using all available resources of technology and the internet. A social phenomenon that ultimately leads a multitude to appropriate the city and to question the status quo through celebration and joy.

Throughout the development of this research, important facts have occurred that will go down in the history of Brazil and Belo Horizonte, and that will help to clarify the relationship between carnival festivities in the state capital and the contemporary climate of major political manifestations in cities. This would be the case of the demonstrations in 2013, the so-called Jornadas de Junho, which took place across the whole country, bringing crowds of people to the streets in a dimension unseen for over 20 years.

The broad agenda of demands from the protests and occupations that took place during the pre and post-Jornadas de Junho periods included the right to live in the city, to appropriate its spaces objectively and subjectively. In Belo Horizonte however, this call to resume the occupation of the streets was nothing new, because since 2009 movements had already been identified that, little by little, were appropriating a variety of city spaces with a mixture of festivity and political protest, as in the case of the street carnival blocks and Praia da Estação. Nonetheless, the demonstrations of 2013 brought a strengthening effect to these movements, and influenced the creation of new movements, such as Tarifa Zero BH and Espaço Comum Luiz Estrela.

In the years 2014 and 2015, carnival in Belo Horizonte exploded, with almost two hundred blocks and more than one million people on the streets. It is probable that within this exponential growth in the number of blocks, many of them were created for purposes other than those proposed by the pioneering blocks with strong political bias. Moreover, the success of the carnival in Belo Horizonte has sparked economic interests and hegemonic politics, which are currently viewing the carnival celebrations as a potential product for generating profit and political power. However, the inclusion of these new subjects, forces and interests diminish neither the festivities nor the discussion, on the contrary, it adds new elements that are already present in the everyday conflicts to the socio-spatial conflicts of the carnival period

However, while the revellers symbolically reinvent the streets during carnival, other city dwellers continue to lead their lives at a normal pace, maintaining their same 
displacement routes between work, home and leisure. In other words, while certain residents wish to party and play in the streets, others seek to raise their banners and make their festive, political protests, and others wish to take advantage of the holiday with rest and peace. Hence, socio-spatial disputes appear, and from these the need for negotiation arises: Is it necessary to register the blocks at the City Hall? Should the number of revellers be limited? Should the streets be fenced off? Should occupying the streets have a time limit? How should the infrastructure, traffic control and street cleaning services be provided? How should the police ensure the safety of revellers, inhabitants and visitors?

In the case of the contemporary carnival in Belo Horizonte, the largest conflict is precisely linked with the very existence of the carnival blocks in the streets. If in the early years - until 2012 - the few blocks that existed suffered repression from the public bodies in the misguided belief that it would restore law and order to the city, in 2015 their significant growth even resulted in a proposal to develop specific legislation for regulating the festivities in order to ensure "democratic occupation and well-organised traffic” (OLIVEIRA, 2015, author's translation).

Initially, dealing with the superficially uncontrolled carnival festivities highlights the tendency of local government in wishing to control all the uses and appropriations that occur in the city, as if solving the conflicts could only occur through legislation, regulations and institutional plans. In this sense, it should be noted that the concepts of space do not necessarily determine its uses and appropriations. Furthermore, in many cases, socio-spatial practices of the population may bring more appropriate, creative solutions than those conceived in the offices of the planning and design department.

In the case of carnival, it was clear that the City Council of Belo Horizonte has experienced difficulties in accepting the festivities as festivities, without craving for profits or other advantages. By eagerly seeking to regulate the street carnival block parades, it is possible that a relationship of dependency and submission could well be created in relation to local government, thus stagnating and discouraging revelry, as befell the samba school parades and caricato blocks in the 1990s.

Another important lesson learned from the experience of carnival blocks in Belo Horizonte concerns the new ways of promoting democratic participation: through festive, political appropriation of city spaces; through the publication of articles, books, manifestos, videos, photos and interviews that help to place important issues onto the debating agenda of society; through groups on the Internet; or even at meetings with public agencies; creating and promoting other discussion channels apart from the traditional. All this has led to a politically healthy pressure that has caused government agencies to change their strategies in relation to the carnival in Belo Horizonte. Therefore, from the explicit example of carnival, it is possible to contemplate planning and management structures that seek to exercise just one interface role within discussions and proposals, allowing projects for the city to be developed from the everyday political negotiations, thus resulting in a collective construction of the city and from experiences of and in the city beyond the institutional bodies.

It should also be noted that the city goes beyond the traditional functionalist view that divides the city into zones, classifies the streets into a hierarchy and transforms space into numbers. The city is alive! It is a piece of work engendered by man and therefore is constantly changing. Humans who inhabit it have needs that 
go beyond the objective demands for home, work and leisure, because they are also formed and constituted by their desires, illusions, knowledge and beliefs that are effective and materialized in different areas of the city. Therefore, when developing policies, urban plans and projects, it is important to consider that the city space is not a tabula rasa, that there exists a series of practices that cannot be grasped by analysing the constructed spaces and the simplistic classifications of use and occupation of land (residential, commercial, mixed, institutional).

Finally, it is important to stress that Carnival is a traditional festival of culture in Brazil and Belo Horizonte, an intangible heritage that deserves encouragement and support. Perhaps the political carnival in Belo Horizonte is unable to promote a revolution, however, its actions and conquests have demonstrated that through sociospatial practices and the various forms of expression, it is possible to promote changes in the manner of both living and living in the city.

\section{REFERENCES}

ACOMPANHE ao vivo a cobertura dos blocos de rua do DF. Correio Brasiliense, Brasília, 14 fev. 2015. Carnaval. Available at: http://www.correiobraziliense.com.br/app/noticia/ cidades/2015/02/14/interna_cidadesdf,471188/acompanhe-ao-vivo-a-cobertura-dosblocos-de-rua-do-df.shtml>. Accessed on: $8^{\text {th }}$ March 2015.

AGENDA Carnaval de Rua SP 2015. O Carnaval de São Paulo, São Paulo, SP, 11 fev. 2015. Agenda do Carnaval. Available at: <http://www.carnavalsp.com.br/agenda-carnaval-de-rua-sp-2015/>. Accessed on: $8^{\text {th }}$ March 2015.

ALMEIDA, B. Previsão se confirma, e BH tem sua maior folia. O Tempo, Belo Horizonte, 21 fev. 2015. Cidades, p. 27.

ALVARENGA, D. Hotéis e receptivos apresentam pacotes para o Carnaval BH 2015. $A B I H-M G$, Belo Horizonte, 8 jan. 2015. Notícias. Disponível em: <http://www. abihmg.com.br/hoteis-e-receptivos-apresentam-pacotes-para-o-carnaval-bh-2015/>. Accessed on: $20^{\text {th }}$ Feb. 2015.

BAETA, J. Baile do Pó Royal é eleita a melhor marchinha no Concurso Mestre Jonas. $O$ Tempo, Belo Horizonte, 15 fev. 2014 Cidades. Available at: <http://www.otempo.com. br/cidades/baile-do-p\%C3\%B3-royal-\%C3\%A9-eleita-a-melhor-marchinha-no-concurso-mestre-jonas-1.789685>. Accessed on: $15^{\text {th }}$ March 2015.

BELO HORIZONTE. Lei no 8.616, de 14 de julho de 2003. Contém o Código de Posturas do Município de Belo Horizonte. CMBH. Available at: <http://www.cmbh.mg.gov.br/ leis/legislacao/pesquisa $>$. Accessed on: 23 $3^{\text {rd }}$ Feb. 2015.

Decreto no 13.798, de 9 de dezembro de 2009. CMBH. Available at: <http://www. cmbh.mg.gov.br/leis/legislacao/pesquisa>. Accessed on: 14 $4^{\text {th }}$ Jan. 2015.

. Decreto no 13.960, de 4 de maio de 2010. Revoga o Decreto no 13.798, de 09 de dezembro de 2009. CMBH. Available at: <http://www.cmbh.mg.gov.br/leis/legislacao/ pesquisa $>$. Accessed on: $14^{\text {th }}$ Jan. 2015.

. Lei no 15.318, de 2 de setembro de 2013. Cria o Conselho Municipal de Mobilidade Urbana - Comurb. CMBH. Available at: <http://www.cmbh.mg.gov.br/leis/legislacao/ pesquisa $>$. Accessed on: $15^{\text {th }}$ March 2015.

O maior carnaval da história da BH. Sala de Notícias, Belo Horizonte, 27 fev. 2014. Available at: <http://portalpbh.pbh.gov.br/pbh/ecp/noticia.do?evento=portlet $\& \mathrm{pAc}=$ not $\& i d C o n t e u d o=146914 \& \mathrm{pIdPl}=\& \mathrm{app}=$ salanoticias $>$. Accessed on: $27^{\text {th }}$ Feb. 2014.
Paola Lisboa Codo Dias: paolacodo@yahoo.com.br

Article received on September $13^{\text {th }}, 2015$ and approved for publication on December $2^{\text {nd }}, 2015$. 
PBH anuncia programação do carnaval 2015 na capital. Diário Oficial do Município, Belo Horizonte, MG, 31 jan. 2015. ano 21. ed. 4736. Available at: <http://portal6.pbh. gov.br/dom/iniciaEdicao.do?method=DetalheArtigo\&pk=1136605>. Accessed on: $20^{\text {th }}$ Feb. 2015.

. Secretaria Municipal Adjunta de Planejamento Urbano. Operação Urbana Isidoro. Belo Horizonte, [201-?] Available at: <http://portalpbh.pbh.gov.br/pbh/ecp/comunidade.do? evento=portlet \&pIdPlc=ecpTaxonomiaMenuPortal\&app=planejamentourbano\&lang=pt_BR\&pg=8843\&tax=35726>. Accessed on: $12^{\text {th }}$ March 2015.

BORGES, G. Confundir: Carnavais e Revoluçôes. Variável 5, Belo Horizonte, 1 fev. 2013. Available at: <http://variavel5.com.br/blog/caps-lock-carnaval/>. Accessed on: $12^{\text {th }}$ Feb. 2014.

BLOCO PUlA CATRACA!. Evento Facebook Bloco Pula Catraca!. 2014. Available at: <https://www.facebook.com/events/231422593709662/>. Accessed on: 16 ${ }^{\text {th }}$ March 2015.

BRANT, A. C. BH bota o bloco na rua. EM, Belo Horizonte, 23 jan. 2012. Carnaval, 2012. Disponível em: <http://www2.em.com.br/app/noticia/especiais/carnaval/2012/01/23/ noticias_internas_carnaval,273843/bh-bota-o-bloco-na-rua.shtml >. Accessed on: $26^{\text {th }}$ March 2014.

CAMILO, J. V. Movimento Tarifa Zero disponibilizará ônibus durante o carnaval. $O$ Tempo, Belo Horizonte, 26 fev. 2014 Cidades. Available at: <http://www.otempo. com.br/cidades/movimento-tarifa-zero-disponibilizar\%C3\%A1-\%C3\%B4nibus-durante-o-carnaval-1.795188>. Accessed on: 21 Nov. 2014.

COSTA, E. Entrevista com representantes dos blocos de carnaval de rua de Belo Horizonte no rádio no programa Chamada Geral. Rádio Itatiaia. Belo Horizonte: 21 fev. 2015. 1 video (23:25 min), son., color. Available at: <https://www.youtube.com/ watch?v=Fjp8YVf28DM\&feature=youtu.be $>$. Accessed on: $22^{\text {nd }}$ Feb. 2015.

CRUZ, M. M. Espaço Comum Luiz Estrela completa um ano em BH. EM, Belo Horizonte, 6 nov. 2014. Divirta-se. Available at: <http://divirta-se.uai.com.br/app/noticia/ musica/2014/11/06/noticia_musica,161142/espaco-comum-luiz-estrela-completa-umano-em-bh.shtml>. Accessed on: $15^{\text {th }}$ March 2015.

DESFILE do Santo Bando é cancelado em Belo Horizonte. G1 MG, Belo Horizonte, 9 fev. 2012. Minas Gerais, Carnaval 2012. Available at: <http://g1.globo.com/minas-gerais/ carnaval/2012/noticia/2012/02/desfile-do-santo-bando-e-cancelado-em-belo-horizonte.html>. Accessed on: $22^{\text {nd }}$ Feb. 2015.

DICKEY, M. R. The 22 key turning points in the history of YouTube. Business Insider, 15 fev. 2013. Available at: <http://www.businessinsider.com/key-turning-points-historyof-youtube-2013-2?op=1>. Accessed on: $18^{\text {th }}$ Jan. 2015.

DINIZ, A.; SANTOS, A. Despejo será a partir de segunda. O Tempo, Belo Horizonte, 9 ago. 2014. Cidades. Available at: <http://www.otempo.com.br/cidades/despejoser\%C3\%A1-a-partir-de-segunda-1.897200>. Accessed on: 10 ${ }^{\text {th }}$ March 2015.

ESPAÇO COMUM LUIZ ESTRELA. Informaçóes da página. Página Facebook Espaço Comum Luiz Estrela (Comunidade). 2013. Available at: <https://www.facebook.com/ espacoluizestrela/info?tab=page_info $>$. Accessed on: $7^{\text {th }}$ Jan. 2015.

FACEBOOK. Company Info | Facebook Newsroom. 2015. Available at: <http://newsroom. fb.com/company-info/>. Accessed on: 16 ${ }^{\text {th }}$ Jan. 2015.

FONTES, L. Samba e Suor (parte 1). Belo Horizonte: 2015a. 1 video (3:13 min), son., color. Jornal O Tempo. Available at: <http://www.otempo.com.br/tv/assista-a-primeira-parte-do-document\%C3\%A1rio-samba-e-suor-1.999627>. Accessed on: $11^{\text {th }}$ March 2015.

Samba e Suor (parte 2). Belo Horizonte: 2015b. 1 video (2:25 min), son., color. Jornal O Tempo. Available at: <http://www.otempo.com.br/tv/assista-a-segunda-partedo-document\%C3\%A1rio-samba-e-suor-1.1004690>. Accessed on: 11 $1^{\text {th }}$ March 2015. 
FRANÇA, F. Sobre carnavais e revoluçōes. Belo Horizonte: 2015. 1 video (11:44 min), son., color. Available at: <https://www.youtube.com/watch?v=PUHcQeRcYNw>. Accessed on: $12^{\text {th }}$ Feb. 2015.

GUIA DOS BLOCOS TRADICIONAIS DE BRASÍLIA. Blocos, [201?]. Available at: <http://www.ligadosblocos.com.br/blocos>. Accessed on: $8^{\text {th }}$ March 2015.

IMAGINA NA COPA. História \#7 - "Praia da Estação". São Paulo: 2013. 1 video (06:32 min), son., color. Imagens e Roteiro: Tiago Pereira. Edição: Apiário. Entrevista: Fernanda Cabral. Available at: <https://www.youtube.com/watch?v=5354OiTR07E/>. Accessed on: 11 $1^{\text {th }}$ Nov. 2014.

JORGE, J. Bloco "Filhos de Tcha Tcha" chega à Ocupação Rosa Leão. 2014. 1 fotografia, color. Formato JPEG. In: Deputado Estadual Rogério Correa website. Available at: <http:// www.rogeriocorreia.com.br/noticia/belo-horizonte-foge-do-pao-e-circo-e-celebra-ocarnaval-tambem-com-politica/>. Accessed on: 21 ${ }^{\text {st }}$ Nov. 2014.

LEITE, F. Tico Tico na Vila Dias | 2013: fotos álbuns. 2013. 1 fotografia, color. Formato JPEG. Available at: <https://www.Facebook.com/media/set/?set $=$ a.652224684844965.1073741830.651617994905634\&type $=3>$. Accessed on: $16^{\text {th }}$ Nov. 2014.

MIRANDA, B. BH terá pacotes para turistas interessados no Carnaval de 2015. O Tempo, Belo Horizonte, 8 jan. 2015. Cidades. Available at: <http://www.otempo.com.br/cidades/ bh-ter\%C3\%A1-pacotes-para-turistas-interessados-no-carnaval-de-2015-1.970509>. Accessed on: $21^{\text {st }}$ Feb. 2015.

MUZZI, L. Maior festa dos últimos anos coloca BH no caminho certo. O Tempo, Belo Horizonte, 6 mar. 2014. Carnaval 2014, p. 13.

NAESSA, D. Evento Facebook ISIDORA: Carnaval e Luta (Estreia). 2015. Available at: <https://www.facebook.com/events/363203043864707/>. Accessed on: 15 $5^{\text {th }}$ March 2015.

OBSERVATÓRIO DAS METRÓPOLES. Manifesto Resiste Isidoro. Notícias, Rio de Janeiro, 26 ago. 2014. Available at: <http://www.observatoriodasmetropoles.net/ index.php?option=com_k2\&view=item \&id=961: manifesto-resiste-isidoro \&Itemid=164\&lang=en $>$. Accessed on: 10 ${ }^{\text {th }}$ March 2015.

OCUPAÇÃO ESPERANÇA. Blog da Ocupaçâo Esperança, na região da Isidora, em Belo Horizonte e Santa Luzia, MG, [201-?]. Available at: <http://ocupacaovitoria.blogspot. com.br/>. Accessed on: $7^{\text {th }}$ Jan. 2015.

OCUPAÇÃO ROSA LEÃO. Blog da Ocupação Rosa Leão, região da Isidora, em Belo Horizonte e Santa Luzia, MG, [201-?]. Available at: <http://ocupacaorosaleao.blogspot.com. br/>. Accessed on: $7^{\text {th }}$ Jan. 2015.

OCUPAÇÃO VITÓRIA. Blog da Ocupação Vitória, regiāo da Isidora, em Belo Horizonte e Santa Luzia, MG, [201-?]. Available at: <http://ocupacaovitoria.blogspot.com.br/>. Accessed on: $7^{\text {th }}$ Jan. 2015.

OLIVEIRA, J. Produtores de blocos e Belotur cobram lei para regulamentar o carnaval em BH. EM, Belo Horizonte, 19 fev. 2015. Gerais. Available at: <http://www.em.com. br/app/noticia/gerais/2015/02/19/interna_gerais,619513/produtores-de-blocos-e-belotur-cobram-lei-para-regulamentar-o-carnaval.shtml>. Accessed on: 19 ${ }^{\text {th }}$ Feb. 2015.

PIMENTEL, J. Blocos: uma história informal do carnaval de rua. Rio de Janeiro: Relume-Dumará; Prefeitura, 2002. Arenas do Rio; 11. 109 p.

PODIA SER PIOR et al. Quem não gosta de samba - Repúdio dos Blocos de Rua do Carnaval de BH ao candidato Marcio: Nota de repúdio. Belo Horizonte, MG, 2012. Available at: $<$ https://www.youtube.com/watch?v=i2bjAv4Cwil>. Accessed on: 12 ${ }^{\text {th }}$ Feb. 2015

PRAÇA LIVRE BH. teaser praia da estação 2. Blog da Praça Livre BH: postagens de "qualquer" natureza sobre a Praça da Estação. Belo Horizonte, 2010. 1 video (01:03 
min), son., color. Available at: <https://pracalivrebh.wordpress.com/2010/01/ page/2/> e <https:/www.youtube.com/watch?v=4mEzQrF6v0M\#t=13>. Accessed on: $28^{\text {th }}$ Feb. 2015

ROCHA, A.; MARTINS, A. Intervenção da PM evita reintegração de casarão. O Tempo, Belo Horizonte, 31 out. 2013. Cidades. Available at: <http://www.otempo.com.br/ cidades/interven \%C3\%A7\%C3\%A3o-da-pm-evita-reintegra\%C3\%A7\%C3\%A3ode-casar\%C3\%A3o-1.739406>. Accessed on: 15 ${ }^{\text {th }}$ March 2015.

ROLNIK, R. Dramase delícias do carnaval. Folha de São Paulo, São Paulo, 9 fev. 2015. Divirta-se. Available at: <http://www1.folha.uol.com.br/colunas/raquelrolnik/2015/02/1587229dramas-e-delicias-do-carnaval.shtml $>$. Accessed on: $4^{\text {th }}$ March 2015.

TARIFA ZERO BH. Carnaval sem catracas. Página Facebook Tarifa Zero BH, 01 mar. 2014 a. Available at: <https://www.facebook.com/tarifazerobh/photos/pb.582305668498014.2207520000.1426479066./679297642132149/?type=3\&theater $>$. Accessed on: $7^{\text {th }}$ Jan. 2015.

Fotos. 2014b. 1 fotografia, color. Formato JPEG. Available at: <https:// ww w. Facebook.com/tarifazerobh/photos/pb. 582305668498014 .$2207520000.1417824845 . / 679297642132149 /$ ?type $=3 \&$ theater $>$. Accessed on: $14^{\text {th }}$ Jul. 2014.

Fotos. 2014c. 1 fotografia, color. Formato JPEG. Available at: <https:// www. Facebook.com/tarifazerobh/photos/pb.582305668498014.$2207520000.1417824845 . / 679297642132149 /$ ?type $=3 \&$ theater $>$. Accessed on: $14^{\text {th }}$ Jul. 2014.

. Carnaval de rua e de luta contra aumento. Página Facebook Tarifa Zero BH, 09 fev. 2015a. Available at: <https://www.facebook.com/tarifazerobh/timeline>. Accessed on: $15^{\text {th }}$ March 2015.

- Mais um carnaval de luta e uma busona que desbrava a cidade. Página Facebook Tarifa Zero BH, 17 fev. 2015b. Available at: <https:/www.facebook.com/tarifazerobh/ timeline>. Accessed on: $15^{\text {th }}$ March 2015.

TRADICIONAL Santo Bando é cancelado na capital. EM, Belo Horizonte, 9 fev. 2012. Gerais. Available at: <http:/www.em.com.br/app/noticia/gerais/2012/02/09/interna_ gerais,276942/tradicional-santo-bando-e-cancelado-na-capital.shtml>. Accessed on: $22^{\text {nd }}$ Feb. 2015.

JUSTIÇA desenvolve trabalho pacífico para reintegração de posse da região Isidoro. Tribunal de Justiça de Minas Gerais, 12 ago. 2014. Available at: <http://www.tjmg.jus.br/portal/ imprensa/noticias/justica-desenvolve-trabalho-pacifico-para-reintegracao-de-posse-daregiao-isidoro.htm\#.VQYTBPnF-VM>. Accessed on: 10 ${ }^{\text {th }}$ March 2015.

VELOSO, A. Um ano do Tarifa Zero BH. Blog Tarifa Zero BH, Belo Horizonte, 26 jun. 2014. Available at: <http://tarifazerobh.org/wordpress/um-ano-do-tarifa-zero-bh/>. Accessed on: $15^{\text {th }}$ March 2015.

R e s U M o: Em Belo Horizonte, os blocos de carnaval surgiram nos tempos de sua fundação, no final do século XIX. Contudo, esse tipo de manifestação foi perdendo sua dimensão e importância a partir dos anos 1930. Na década de 1990, Belo Horizonte passou a ser conhecida pelo sossego que pairava em suas ruas durante o feriado carnavalesco. A primeira década do século XXI marca a inflexão desse processo no periodo pré-carnavalesco, enquanto o ano de 2009 representa o início do movimento de retomada dos blocos de rua durante o feriado oficial. Desde então, ocorreu uma completa transformação do carnaval belo-horizontino, passando de uma festa decadente, marginalizada e quase esquecida pela 
PAOLA LISBOA CODO DIAS

maioria da população ao grande sucesso de uma festa efervescente e exuberante. Assim, este artigo pretende trazer discussóes e olhares inabituais sobre o espaço da metrópole contemporânea a partir da reflexão sobre a apropriação da cidade pela festa carnavalesca.

P A L A V R A S - C H A V E : apropriação socioespacial; carnaval de rua; blocos de carnaval contemporâneos; manifestaçôes festivo-politicas; conflitos socioespaciais na metrópole. 